\title{
Hospital-associated functional decline and possible interventions based on physical activity, a review of the literature
}

\author{
Bethia Pacheco', Luis Carlos Venegas-Sanabria ${ }^{1,2}$, Diego A. Chavarro-Carvajal1,2 \\ 'Instituto de Envejecimiento. Facultad de Medicina, Pontificia Universidad Javeriana. Bogotá. Colombia. ${ }^{2}$ Unidad de Geriatría Hospital Universitario San Ignacio. Bogotá. Colombia.
}

doi: 10.18176 /archmeddeporte.00018

Received: $28 / 11 / 2019$

Accepted: 18/09/2020

Key words:

Functional decline. Dependence.

Physical activity. Hospitalization.

\section{Summary}

Hospital functional impairment is defined as the loss of the ability to perform at least one of the basic activities of daily living with respect to the baseline situation of the person (2 weeks before the onset of acute illness). Its prevalence has been increasing due to the demographic transition of the last few years, which has caused aging to become a challenge with great impact on the health of people, their families and the health system. One of the main consequences of the increase in hospitalizations in the elderly is hospital functional impairment. This condition has multiple consequences in the short, medium and long term, which include increased hospital stay, increased costs of care, increased morbidity and mortality, among others. One of the stages of hospital functional impairment, which corresponds to the functional decline during hospitalization, is modifiable; hence the importance of identification and timely management to intervene at risk patients. Among the interventions that are proposed to deal with this condition are specialized geriatric care, comprehensive management with a multidisciplinary team, nutritional support and physical activity. The latter has been shown to have beneficial effects on physical, cognitive and neuropsychiatric symptoms in the elderly; Therefore, it has been included in multiple hospital protocols as the main nonpharmacological intervention to reduce dependence and impact on functional hospital deterioration.

The objective of this literature review is to describe the definition, epidemiology, risk factors, complications, factors associated with functional recovery and intervention programs described for the treatment. Additionally, describe the interventions that include physical activity in elderly patients hospitalized for acute pathologies and possible functional outcomes in this population.

\section{Deterioro funcional hospitalario y posibles intervenciones desde la actividad física, una revisión de la literatura}

\begin{abstract}
Resumen
El deterioro funcional hospitalario (DHF) se define como la pérdida de la capacidad de realizar al menos una de las actividades básicas de la vida diaria respecto a la situación basal de la persona (2 semanas antes del inicio de la enfermedad aguda). Su prevalencia va en aumento por la transición demográfica de los últimos años que ha generado que el envejecimiento se convierta en un reto con gran impacto en la salud de las personas, sus familias y el sistema sanitario. Una consecuencia importante en la hospitalización de los ancianos es el deterioro funcional hospitalario. Esta condición tiene múltiples consecuencias a corto, mediano y largo plazo dentro de las que se incluyen: aumento de la estancia hospitalaria, aumento de los costos en la atención, aumento de la morbimortalidad, entre otros. Una de las etapas del DFH, que corresponde a la declinación funcional durante la hospitalización, es modificable; de allí la importancia de la identificación y manejo oportuno para intervenir a los pacientes en riesgo. Dentro de las intervenciones que se plantean para lidiar con el DFH se encuentra la atención geriátrica especializada, el manejo integral con un equipo multidisciplinario, el soporte nutricional y la actividad física. Está última, ha demostrado tener efectos beneficiosos sobre la función física, cognitiva y síntomas neuropsiquiátricos en el adulto mayor; por lo que se ha incluido en múltiples protocolos hospitalarios como principal intervención no farmacológica para disminuir la dependencia e impactar en el deterioro funcional hospitalario.

El objetivo de esta revisión de literatura es describir la definición, epidemiología, factores de riesgo, complicaciones, factores

asociados a la recuperación funcional y programas de intervención descritos para el tratamiento del DFH. Adicionalmente describir las intervenciones que incluyan actividad física en los pacientes adultos mayores hospitalizados por patologías agudas y los posibles resultados funcionales en esta población.
\end{abstract}

Palabras clave: Deterioro funcional. Dependencia. Actividad física. Hospitalización.

Correspondence: Diego Andrés Chavarro Carvajal

E-mail: chavarro-d@javeriana.edu.co 


\section{Introduction}

The demographic transition that has been taking place in recent decades has meant that aging has become a global challenge with major implications for the health of people and their families, and health systems ${ }^{1}$.

The World Health Organization (WHO) states that most of the population has a life expectancy of over 60 for the first time in history ${ }^{2}$. In addition, the aging pattern is much faster than in the past ${ }^{2}$; and these demographic alterations have led to changes in health conditions which have become prevalent, affecting public health ${ }^{3}$.

It is estimated that about $10 \%$ of the elderly require hospitalisation for acute medical conditions at least once a year ${ }^{4}$. One of the most frequent consequences of this hospitalisation in this population group is hospital-associated functional decline (HFD) ${ }^{4,5}$. HFD has short-, medium- and long-term consequences, and some of these can be severe, leading to a significant consumption of social and health resources ${ }^{6}$.

Physical activity is known to be a fundamental non-pharmacological strategy for healthy aging? ${ }^{7}$. It has been shown to have beneficial effects on physical and cognitive functions, and the control of neuropsychiatric symptoms in the elderly ${ }^{8}$. For this reason, it has been included in many health maintenance programmes for such patients and in geriatric rehabilitation plans as an important therapeutic intervention to prevent frailty and dependence ${ }^{4,9}$, conditions which have an impact on the physical and cognitive functions ${ }^{9}$.

This literature review aims to define HFD, describe its epidemiology and the risk factors and complications involved, and report on intervention programmes involving physical activity for elderly patients hospitalised for acute medical conditions.

\section{Methodology}

This paper is based on a review of the available literature on hospital-associated functional decline and physical activity, and is presented as a narrative review.

\section{Definition}

Hospital-associated functional decline (HFD) has been defined on many occasions in terms of loss of function or dependency, decline in the basic activities of daily living (ADLs) and instrumental activities of daily living (IADLs), state of decline and functional impairment ${ }^{6}$. This paper will use the definition most widely accepted and used in recent years. HFD is understood as the loss of the ability to perform at least one of the basic activities of daily living compared to the person's baseline situation ( 2 weeks before the onset of an acute medical condition) ${ }^{10}$. This deterioration is more related to certain characteristics of the elderly person than the severity of the acute condition itself $\mathrm{f}^{1-12}$. The literature describes two stages of functional decline: a non-modifiable one corre- sponding to the acute onset of the condition until admission to hospital and then functional decline once hospitalised ${ }^{3,4}$. This second stage is very important because it can be changed when detected and treated early; hence the importance of hospital protocols for early intervention for patients at risk.

\section{Epidemiology}

The prevalence of HFD is estimated at between 35 and $70 \%$ among inpatients over 60, with an incidence on discharge of between 35 and $50 \%{ }^{4}$. The literature shows that the prevalence of HFD on discharge is directly proportional to age. It is estimated that it stands at $46 \%$ in the over-70s and $88 \%$ in the over-90s 4 . Studies with a follow-up after 3 months show the persistence of decline in one or more ADLs in 19\% of the population and in $28 \%$ after one year ${ }^{4,5}$, this being associated with increased mortality ${ }^{13,14}$

\section{Risk factors and identification of patients}

HFD is a multifactorial condition more related to the characteristics of the individual and those of hospitalisation than with the severity and characteristics of the acute condition suffered by the patient $t^{4,11,12}$.

\section{Age}

The older the patient, the greater the risk of HFD. This has been demonstrated in several studies in which prevalences of up to $23 \%$ at the age of 70 and rising to up to $50 \%$ in over-85s have been described $5,15,16$

\section{Changes with aging}

With aging, the expected physiological changes include musculoskeletal changes, loss of muscle mass (sarcopenia), fatty infiltration and decreased bone mineral density, leading to decreased strength, aerobic capacity, frailty and more frequent fall $s^{4,17}$. At metabolic level, visceral fat and fatty infiltration of tissues increase, beta-cell mass decreases and the production of adipokines and inflammatory factors augment, leading to proinflammatory states, insulin resistance and a higher prevalence of acute conditions or decompensation of chronic conditions ${ }^{18}$. At cardiac level, the number of cardiomyocytes decreases, and cardiac hypertrophy and vascular stiffness appear, producing greater endothelial dysfunction, vasomotor instability and pulmonary ventilation impairment ${ }^{4,18}$ Neurosensory changes include reduced brain mass and increased cerebrospinal fluid, resulting in a slower processing speed, less focusing of neuronal activity, decreased working memory and, perhaps among the most important consequences, reduced motor skill ${ }^{18}$.

\section{Baseline situation}

The risk factors associated with the individual also include the baseline situation of the patient ( 2 weeks before the onset of the acute medical condition). Some studies have documented that elderly patients 
in a good baseline situation are 2.5 times more likely to recover their baseline state, while those moderately dependent for ADLs (defined as a score lower than 60 on the Barthel scale) are at greater risk of HFD and of it persisting longer beyond discharge $e^{4.19-21}$.

\section{Delirium}

Delirium is very frequent among elderly inpatients ${ }^{5}$, with a prevalence of 14 to $24 \%{ }^{22}$. Although the mechanism which links them is not known, this is presumed to be due to the increased frequency of falls, incontinence, immobility due to restraints, adverse drug reactions, pressure sores and greater time in hospital $\left.\right|^{5,23,24}$.

\section{Cognitive impairment}

Cognitive decline has been identified in several studies as a risk factor for worse outcomes following hospital discharge ${ }^{25,26}$. Sands et al. demonstrated a relationship between cognitive function and functional evolution during hospitalisation ${ }^{26}$. This implies that it is important to carry out an early assessment of the cognitive function of elderly patients admitted to hospital for acute medical conditions.

\section{Depressive symptoms}

The prevalence of depressive symptoms in elderly inpatients ranges from 10 to $25 \%$ depending on the diagnostic criteria used ${ }^{27}$ and such symptoms are related to a three-times greater risk of HFD ${ }^{28,29}$.

\section{Polypharmacy}

The greater the quantity of medications used, the greater the risk of incorrect prescription and adverse drug reactions ${ }^{30}$. Benzodiazepines and neuroleptics are among the medications which most affect mobility and balance ${ }^{31}$. Elderly patients are more sensitive to the effects of these medications and are slower to eliminate them due to changes in pharmacodynamics and pharmacokinetics resulting from the kidney disorders associated with aging, leading to more complications, such as delirium, falls and fractures ${ }^{5,32}$. Drug reactions are involved in the development of 20 to $25 \%$ of HFD ${ }^{6,33}$.

\section{Immobility}

During hospitalisation, elderly patients have low levels of activity and mobility and a relationship between time in bed and drop in Barthel scale score has been described ${ }^{34}$. Studies estimate that elderly patients are immobile for 73 to $83 \%$ of their time in hospita ${ }^{35}$. Immobility is of the utmost importance in the first 48 hours of bed rest, which is when it has the greatest impact on reducing functional reserve and aerobic capacity ${ }^{4}$. It is one of the most relevant risk factors because it is susceptible to modification ${ }^{5}$.

\section{Environment and hospital routines}

Hospital care usually focuses on the diagnosis and treatment of acute medical conditions and often leaves aside cognitive, social, family and functional considerations in the elderly ${ }^{36}$. Many practices contribute to the low mobility of patients, such as the prolonged use of catheters, physical restraints, excessive fear of their falling, acts which disrupt their sleep and the overuse of psychotropic drugs. Such measures probably have no major impact on young people but do on the elderly ${ }^{5.6}$. Physical barriers also pose a problem for mobility. These include raised beds, low chairs, non-adapted bathrooms, poor lighting and obstacles that increase the risk of falls $s^{5,6}$.

\section{Identifying patients at risk}

The timely detection of patients at risk would facilitate the early initiation of specific interventions to prevent dependency and the need for residential care, and reduce morbimortality and health costs ${ }^{4,9,37}$. Patients at risk need to be detected in the first 48 hours following admission in order to reduce the associated complications ${ }^{4}$. Easy-to-apply screening scales exist to identify patients at risk, including, for example, the tools Hospital Admission Risk Profile (HARP), Identification of Seniors at Risk of Functional Decline (SHERPA), Identification of Seniors at Risk (ISAR) and the social-familial GIJÓN scale $e^{5,38}$.

\section{Complications}

Hospital-associated functional decline has multiple consequences for the health in the short, medium and long terms. These include longer times in hospital, greater use of physical resources, higher health costs, higher readmission rates, loss of autonomy, greater functional dependency, more need for residential care and increased mortality $3-6,17,19,39$. Furthermore, a relationship between not recovering functionally following discharge and increased mortality has been described ${ }^{5,6,40-42}$.

\section{Factors associated with functional recovery}

The factors associated with functional recovery include the early detection of risk factors which benefit from early intervention, the baseline situation at the time of admission (good previous functional reserve) and the potential for recovery ${ }^{4-6,43,44}$.

\section{Interventions}

\section{Specialised geriatric care and a multidisciplinary team}

A type of intervention which has shown some of the best results with elderly inpatients is comprehensive geriatric care ${ }^{5,6}$. This includes multidisciplinary care and a suitable environment for the population, monitoring their entire functional development. It involves geriatric units specialised in the hospital setting with detection and treatment protocols for geriatric syndromes, a multidisciplinary team and early planning for discharge $38,45,46$. 


\section{Nutritional support}

The backing of clinical nutrition is very important for elderly patients. Protein intake is important for maintaining muscle mass and potentially increasing muscle strength ${ }^{4-6}$. The recommendations indicate a protein intake of at least $1.2 \mathrm{~g} / \mathrm{kg} /$ day for over-65s, combined with physical activity, in order to maintain and restore lean mass ${ }^{47}$.

\section{Physical activity}

Physical activity is one of the most relevant non-pharmacological strategies for healthy aging. There are many definitions covering it, so we must start by describing them and differentiating concepts.

WHO defines physical activity as any bodily movement produced by the skeletal muscles that requires energy expenditure ${ }^{48}$. AMEDCO (Sports Medicine Association of Colombia) describes it as any voluntary bodily movement requiring muscle contraction and higher-than-baseline energy expenditure, understood as a complex, voluntary, autonomous human behaviour involving components of a biological, psychological and socio-cultural nature ${ }^{49}$. Physical activity should be distinguished from the activities necessary to stay alive and those aimed at improving the health and lifestyle ${ }^{50}$. The American College of Sports Medicine (ACSM) says that physical activity means moving voluntarily and increasing the metabolism as a result of muscle activity ${ }^{51}$.

According to $\mathrm{WHO}$, exercise is a subcategory of physical activity that is planned, structured, repetitive, and purposeful in the sense that its objective is to improve or maintain one or more components of physical fitness ${ }^{2,52-54}$.

The beneficial effects of physical activity on the health are associated with the modification of biological and psychosocial variables which protect against cardiovascular disease, increase the neurotrophic capacity of the brain, support the growth and maintenance of neural circuits, improve cerebral perfusion and circulation, and increase and maintain muscle mass, among other thing $s^{8}$.

Physical activity is one of the factors that conditions body activity and favours multiple changes in body composition over the long term, depending on the amount of energy expended and the frequency, intensity and duration of exercise carried out ${ }^{55}$. The benefits of structured physical exercise for the elderly include: decreased incidence of cardiovascular disease; the maintenance of adequate nutritional and metabolic balance; the postponement of insulin resistance associated with aging, reduced bone mineral loss by boosting osteoblastic hormonal activity and bone remodelling; reduced risk of fracture; reduced risk of falls; strengthening of the muscles; improved balance, coordination and agility; the preservation of cognitive function; decreased prevalence of depression; and enhanced social integration ${ }^{8,56,57}$.

A sedentary lifestyle is the main cause of low levels of physical activity and was defined by WHO in 2002 as "little agitation or movement" 58 . In energy terms, a person is considered sedentary when they do not increase on the energy they spend at rest (BMR) by more than $10 \%$ in their daily activities ${ }^{59}$.
Studies conducted by WHO and $\mathrm{PAHO}$ show that three quarters of the Latin American population have a sedentary lifestyle, with women and the poor leading the trend. The level of physical activity of the elderly population is low compared to studies in some Latin American countries, which highlight lower participation as the population ages ${ }^{60}$

Prolonged inactivity entails a marked and progressive reduction of muscle mass, flexibility and balance ${ }^{61}$. Inactive behaviour is very common among elderly inpatients. The effects include a loss of muscle mass and aerobic capacity, and increased neuropsychiatric symptoms ${ }^{62}$. In elderly inpatients, physical inactivity is associated with the time patients are alone in their room. They are more immobile in the afternoon, accompanied by neuropsychiatric symptoms ${ }^{62}$.

In the hospital environment, multiple factors are described which prevent inpatients from carrying out physical activity; many of these are modifiable. They include, in addition to the symptoms of the condition itself, the use of medical devices (urinary catheters, prolonged use of venous catheters, fear of falling, etc. ${ }^{63}$.

As for the standardised creation of physical activity programmes, a major hindrance is the heterogeneity in the way that the mobility of hospitalised adults is measured and defined. In practice, it has been difficult to identify the subgroups of patients who benefit the most from interventions, define the appropriate dose and pinpoint the best time to implement the programmes ${ }^{64,65}$.

\section{Exercise programmes described in the literature}

It has been reported that physical training, especially of the lower body, can help preserve and improve functional capacity in the elder$\mid y^{66}$. There is evidence that the muscles of older people respond well to intense physical training ${ }^{66}$. Programmes of this kind were first described in 2007 in a Cochrane systematic review with physical activity rehabilitation interventions, walks 3 times a day, changes of position and physical therapy, showing a better functional outcome when physical activity was included compared to conventional hospital care ${ }^{67}$.

Subsequently, physical activity programmes tailormade for the patient have been described, showing uncertain results; not so when more specific subpopulations or groups of medical conditions have been evaluated ${ }^{63}$.

In another meta-analysis of inpatient rehabilitation programmes for the geriatric population which included 17 clinical experiments that evaluated the effect of rehabilitation (including physiotherapy, occupational therapy or both) compared to conventional care, the results in terms of functional improvement were satisfactory, with a significant decrease in mortality and the need for residential care ${ }^{67}$.

In order to prevent functional decline, physical activity programmes should be initiated within 24 hours of hospital admission 68 and include walking at least twice a day for 20 minutes, and the exercise should be graded, while the optimal dose for prescription is unknown ${ }^{68}$

As for the duration of interventions, the most recent studies suggest that programmes should be implemented for at least 3 months to 
improve physical performance in older adults ${ }^{69}$. Therefore, it is proposed that interventions to prevent physical inactivity should probably be more progressive and adapted to the patient, and not just limited to their time in hospita ${ }^{62,69}$. While the patient is in hospital, it is proposed that the therapy sessions be customised in order to have impact on the times of the day in which greater immobility is displayed (in the afternoon $)^{61}$. One of the most important strategies for effective physical activity programmes is encouragement of the participation of medical staff and family in the comprehensive care of the patient ${ }^{61,66}$.

\section{Conclusion}

HFD is a very common condition among the elderly population of multifactorial origin with multiple associated complications. It is important to identify patients at risk early in order to initiate interventions to promote the autonomy and functional recovery of this population group. Numerous interventions are described in the literature and one of the most important of these is physical activity; however, although its potential benefits when it comes to preventing frailty and dependency, both conditions which affect physical and cognitive functions, are known, there are no methodological models for prescribing exercise for older people in our hospital environment.

\section{Conflict of interest}

The authors declare that they are not subject to any type of conflict of interest.

\section{Bibliography}

1. Gaviria Uribe A. Envejecimiento demográfico: Colombia 1951-2020 dinámica demográfica y estructuras poblacionales. Bogotá: Ministerio de Salud y Protección Social. 2013. (consultado 0810/2019). Disponible en www.who.int

2. OMS. Envejecimiento y salud. 2018. (consultado 0810/2019). Disponible en: https:// www.who.int/es/news-room/fact-sheets/detail/envejecimiento-y-salud

3. Córcoles-Jiménez MP, Ruiz-García MV, Saiz-Vinuesa MD, et al. Deterioro funcional asociado a la hospitalización en pacientes mayores de 65 años. Enferm Clin. 2016; 26:121-8.

4. Lozano Rengifo MJ, Chavarro Carvajal DA. Deterioro funcional hospitalario. Revisión y actualización con una perspectiva orientada a mejorar la calidad de atención del anciano. Univ Médica. 2017;(27)58:1-6.

5. Osuna-Pozo CM, Ortiz-Alonso J, et al. Revisión sobre el deterioro funcional en el anciano asociado al ingreso por enfermedad aguda. Rev Esp Geriatr Gerontol. 2014;49:77-89.

6. Ocampo JM. Revisión sistemática de literatura. Declinación funcional en ancianos hospitalizados. Rev Médica Risaralda. 2016;30;22:49-57.

7. Izquierdo M, Casas-Herrero A, Zambom-Ferraresi F, et al. Multicomponent Physical Exercise program VIVIFRAIL; 2017. (consultado 0810/2019) Disponible en: www.vivifrail. com/es/documentación.

8. Aparicio Garca-Molina VA, Carbonell-Baeza A, Delgado-Fernández M. Health benefits of physical activity in older people. Rev Int Med y Ciencias la Act Fis y del Deport. 2010;10:556-76.

9. Torres A, Rivera A, Mendivelso O, et al. Analysis of functional risk and sociofamily deterioration in hospitalized elderly patients. Rev Medica Sanitas. 2019;22:6-16. Available from: https://doi.org/10.26852/01234250.30

10. Fretwell MD, Raymond PM, McGarvey ST, et al. The Senior Care Study: A controlled trial of a consultative/ unit based geriatric assessment program in acute care. J Am Geritr Soc. 1990;38:1073-81.

11. Harris RD, Henschke PJ, Popplewell PY, et al. A randomised study of outcomes in a defined group of acutely ill elderly patients managed in a geriatric assessment unit or a general medical unit. Aust NZ J Med.1991;21:230-4
12. Boyd CM. Recovery in activities of daily living among older adults following hospitalization for acute medical illness. J Am Geriatr Soc. 2008:2171-9.

13. Covinsky KE, Justice $A C$, Rosenthal GE, et al. Measuring prognosis and case mix in hospitalized elders: The important of functional status. J Gen Intern Med. 1997;12:203-8

14. Gómez JF. Salud del anciano: valoración. Manizales, Caldas: Blanecolor; 2014.

15. Sager MA, Franke T, Inouye SK, et al. Functional outcomes of acute medical illness and hospitalization in older persons. Arch Intern Med. 1996;156:645-52.

16. Mañas MD, Marchán E, Conde $C$, et al. Functional impairment in elderly patients hospitalised in an internal medicine unit. An Med Interna. 2005;22:130-2.

17. Sepúlveda $D$, Isach $M$, Izquierdo G, Ruipérez I. Functional decline in nonagenarians admitted at acute care hospitals. Med Clin (Barc). 2001;116:799

18. Salech F, Jara R, Michea L. Cambios fisiológicos asociados al envejecimiento. Rev Médica Clínica Las Condes. 2012;23:19-29.

19. Baztán JJ, González M, Morales C, et al. Variables asociadas a la recuperación funcional y la institucionalización al alta en ancianos ingresados en una unidad geriátrica de media estancia. Rev Clin Esp. 2004;204:574-82.

20. Abizanda P, León M, Romero L, Sánchez PM, et al. La pérdida funcional al ingreso, principal variable explicativa de discapacidad y mortalidad al alta y al mes en ancianos hospitalizados. Rev Esp Geriatr Gerontol. 2007;42:201-11.

21. Volpato S, Onder G, Cavalieri M, et al. Characteristics of nondisabled older patients developing new disability associated with medical illnesses and hospitalization. J Gen Intern Med. 2007;22:668-74.

22. Inouye SK. Delirium in older persons. N Engl J Med. 2006;354:1157-65.

23. Young J, Inouye SK. Delirium in older people. BMJ. 2007;334:842-6.

24. Francis J, Kapoor WN. Delirium in hospitalized elderly. J Gen Intern Med. 1990;5:65-79.

25. Sands LP, Yaffe K, Covinsky K, et al. Cognitive screening predicts magnitude of functional recovery from admission to 3 months after discharge in hospitalized elders. J Gerontol A Biol Sci Med Sci. 2003; 58: 37-45.

26. Covinsky KE, Fortinsky RH, Palmer RM, et al. Relation between symptoms of depression and health status outcomes in acutely ill hospitalized older persons. Ann Intern Med. 1997;126:417-25.

27. Blazer DG. Late-life mood disorders. Halter JB. Hazzard's Geriatric Medicine and Gerontology 6th ed. New York: Mc Graw Hill; 2009.

28. Fick DM, Semla TP. American Geriatrics Society Beers Criteria: New year, new criteria, new perspective. J Am Geriatr Soc. 2012;60:614-5.

29. Lin HY, Liao CC, Cheng SH, et al. Association of potentially inappropriate medication use with adverse outcomes in ambulatory elderly patients with chronic diseases: Experience in a Taiwanese medical setting. Drugs Aging. 2008;25:49-59.

30. American Geriatrics Society 2012 Beers Criteria Update Expert Panel. American Geriatrics Society updated Beers Criteria for potentially inappropriate medication use in older adults. J Am Geriatr Soc. 2012;60:616-31.

31. Sager MA, Buurman BM, Korevaar JC, et al. The prediction of functional decline in older hospitalized patients. Age Ageing. 2012;41:381-7.

32. Pedone C, Ercolani S, Catani M, et al. Elderly patients with cognitive impairment have a high risk for functional decline during hospitalization: The GIFA Study. J Gerontol A Biol Sci Med Sci. 2005;60:1576-80.

33. Callen BL, Mahoney JE, Grieves CB, et al. Frequency of hallway ambulation by hospitalized older adults on medical units of an academic hospital. Geriatr Nurs. 2004;25: 212-7.

34. Inouye SK, Wagner DR, Acampora D, et al. A predictive index for functional decline in hospitalized elderly medical patients. J Gen Intern Med. 1993;8:645-52.

35. Martínez-Velilla N, Urbiston-Lasa G, Veitemilla-Erice E, Cambra-Contín K. Cuantificación de las horas de encamamiento en pacientes hospitalizados por afección médica y deterioro funcional y mortalidad secundarios. Rev Esp Geriatr Gerontol. 2013;48:96.

36. Thomas DR. Focus on functional decline in hospitalized older adults. The journals of gerontology Series A, Biol Sci Med Sci. 2002;57:M567-8.

37. Sager MA, Rudberg MA, Jalaluddin M, et al. Hospital Admission Risk Profile (HARP): Identifying older patients at risk for functional decline following acute medical illness and hospitalization. J Am Geriatr Soc. 1996;44:251-7.

38. Yao JL, Fang J, Lou QQ, Anderson RM. A systematic review of the identification of seniors at risk (ISAR) tool for the prediction of adverse outcome in elderly patients seen in the emergency department. Int J Clin Exp Med. 2015;8:4778-86.

39. Hoogerduijn JG, Schuurmans MJ, Korevaar JC, Buurman BM, de Rooij SE. Identification of older hospitalized patients at risk for functional decline, a study to compare the predictive values of three screening instruments. Journal of clinical nursing. 2010;19:1219-25

40. Landefeld CS, Palmer RM, Kresevic DM, Fortinsky RH, Kowal J. A randomized trial of care in a hospital medical unit especially designed to improve the functional outcomes of acutely ill older patients. N Engl J Med. 1995;332:1338-44. 
41. Zuckerman JD. Hip fracture. N Engl J Med. 1996;334:1519-25.

42. Rudberg MA, Sager MA, Zhang J. Risk factors for nursing home use after hospitalization for medical illness. J Grontol A. Biol Sci Med Sci. 1996;277:881-2.

43. Palleschi L, de AlfieriW, Salani B, et al. Functional recovery of elderly patients hospitalized in geriatric and general medicine units. The PROgetto DImissioni in GEriatria Study. J Am Geriatr Soc. 2011;59:193-9.

44. Baztán JJ, Cáceres LA, Llanque JL, Gavidia JJ, Ruipérez I. Predictors of functional recovery in older hospitalized adults. J Am Geriatr Soc. 2012;60:187-9.

45. Baztán JJ, Suárez-García FM, López-Arrieta J, et al. Effectiveness of acute geriatric units on functional decline, living at home, and case fatality among older patients admitted to hospital for acute medical disorders: Meta-analysis. BMJ. 2009;338: b50.

46. Covinsky KE, Palmer RM, Counsell SR, Pine ZM, Walter LC, Chren MM. Functional status before hospitalization in acutely ill older adults: validity and clinical importance of retrospective reports. J Am Geriatr Soc. 2000;48:164-9.

47. León Ortiz M, Ariza Zafra M. Valoración nutricional en el anciano. En: Abizanda Soler P, Rodríguez Mañas L, editores. Tratado de medicina geriátrica: fundamentos de la atención sanitaria a los mayores. Madrid: Elsevier; 2014. p. 204-12

48. OMS. OMS|Actividad física. WHO. 2013. (consultado 0810/2019) Disponible en: https:// www.who.int/dietphysicalactivity/pa/es/

49. Asociación de Medicina del Deporte de Colombia. Manifiesto de Actividad Física para Colombia. 2002. (consultado en 0810/2019) Disponible en: http://amedco.encolombia. com/componentes-manifiesto.htm

50. Guillen del Castillo M, Linares D. Bases biológicas y fisiológicas del movimiento humano. España: Panamericana; 2002

51. Organización Panamericana de la Salud. Estrategia mundial OMS sobre régimen alimentario, actividad física y salud (DPAS). Plan de ejecución en América latina y el Caribe 2006-2007. (consultado en 0810/2019). Disponible en: https://www.who.int/ dietphysicalactivity/strategy/eb11344/strategy_spanish_web.pdf

52. OMS. Envejecimiento y salud. 2018. (consultado en 0810/2019) Disponible en: https:// www.who.int/es/news-room/fact-sheets/detail/envejecimiento-y-salud

53. OMS. Fisioterapia OMS 2018 - Definiciones y Estado Actual - Fisioterapia online. (consultado en 2110/2019) WHO. 2018. Disponible en: https://www.blogdelfisioterapeuta. com/fisioterapia-oms/

54. OPS. OPS/OMS | Rehabilitación. OPS. 2018. (consultado en 2110/2019). Disponible en: https://www.paho.org/hq/index.php?option=com_content\&view=article\&id=13919 :rehabilitation\&ltemid=41651\&lang=es

55. Kyle UG, Genton L, Gremion G, et al. Aging, physical activity and height-normalized body composition parameters. Clin Nutr. 2004; 23:79- 88

56. Audelin MC, Savage P. y Ades PA. Exercise-Based Cardiac Rehabilitation for Very Old Patients (>75 Years) Focus on physical function. J Cardy Rehab Prev. 2008; 28:163-173.
57. Castillo-Garzón MJ, Ruiz JR, Ortega FB y Gutiérrez A. Anti-aging therapy through fitness enhancement. Clin interven aging. 2006;1:213-220

58. Serrato M. Nuevas tendencias en recomendaciones de actividad física y prescripción del ejercicio. Bogotá: AMEDCO; 2003.

59. Correa J. Documento marco que sustenta la relación del grupo de investigación en actividad física y desarrollo humano con los currículos de programas de pregrado de rehabilitación de la escuela de Medicina y Ciencias de la Salud. Bogotá: Universidad del Rosario; 2010. (consultado 2110/2019). Disponible en: https://repository.urosario.edu. co/bitstream/handle/10336/3799/Documento\%2002_sextas\%20artes_IMPRENTA pdf? sequence $=4$

60. Organización Panamericana de la Salud (OPS). La inactividad física: Un factor principa de riesgo para la salud en las Américas. Programa de Alimentación y Nutrición / División de Promoción y Protección de la Salud. 2002. (consultado 2110/2019) Disponible en URL: http://www.ops-oms. org/Spanish/HPP/HPN/whd2002-factsheet3.pdf

61. Belala, N., Maier, C., Heldmann, P. et al. A pilot observational study to analyze (in)activity and reasons for sedentary behavior of cognitively impaired geriatric acute inpatients. Gerontol Geriat. 2019; 52(Suppl 4): 273-281. DOI: 10.1007/s00391-019-01644-X

62. Koenders $N$, Weenk M, Van de Belt T, et al. Exploring barriers to physical activity of patients at the internal medicine and surgical wards: a retrospective analysis of continuously collected data, Disab Rehab. 2019; 1-7. DOI: 10.1080/09638288.2019.1685013

63. Fazio S, Stocking J, Kuhn B, et al. How much do hospitalized adults move? A systematic review and metaanalysis. App/ Nursing Res. 2020; 51:151189.

64. Suetta C, Magnusson SP, Beyer N, Kjaer M. Effect of strength training on muscle function in elderly hospitalized patients. Scand J Med Sci Sports. 2007;17:464-72.

65. Serra-Rexach JA, Bustamante-Ara N, Hierro Villarán M, et al. Short-term, light-to moderate-intensity exercise training improves leg muscle strength in the oldest old a randomized controlled trial. J Am Geriatr Soc. 2011;59:594-602.

66. De Morton NA, Keating JL, Jeffs K. Exercise for acutely hospitalized older medical patients. Cochrane Database Syst Rev. 2007:CD005955

67. Bachmann S, Finger C, Huss A, Egger M, Stuck AE, Clough-Gorr KM. Inpatient rehabilitation specifically designed for geriatric patients: systematic review and meta-analysis of randomized controlled trials. BMJ. 2010; 340: c1718

68. Ley L, Khaw D, Duke M, Botti M. The dose of physical activity to minimise functional decline in older general medical patients receiving 24-hr acute care: A systematic scoping review. J Clin Nurs. 2019;28:3049- 3064. https://doi.org/10.1111/jocn.14872

69. Scheerman K, Raaijmakers K, Otten R, Meskers C, Maier A. Effect of physical interventions on physical performance and physical activity in older patients during hospitalization: a systematic review. BMC Geriatrics. 2018;18:288. 